\title{
Effect of cerium incorporation on the structure of hydrous rhyolitic melt
}

\author{
NOZOMI KONDO1, Yoshio KonO2, KoJI OHARA3, \\ ETIENNE SKRZYPEC4, AKIHIRO YAMADA5, SATOSHI \\ SAITO6 \\ 1Geodynamics Research Center, Ehime University, \\ kondo.nozomi.xg@ehime-i.ac.jp \\ 2 Geodynamics Research Center, Ehime University \\ 3SPring-8 synchrotron facility, Japan Synchrotron Radiation \\ Reseach Institute \\ 4Institute if Earth Science, Graz University \\ 5Center of Glass Science and Technolohy, The University of \\ Shiga Prefecture \\ 6Department of Earth Science, Graduate School of Science \\ and Engineering
}

Cerium (Ce) in silicate melts is considered to provide inportant information about the nature of silicate magmas in the Earth's nad planetaly interiors, and especially their oxidation state. However, the behavior of $\mathrm{Ce}$ in a silicate melt structure may not be simple, paticularly in hydrous silicate melt where a strong depression of the $\mathrm{Ce}_{4+} / \mathrm{Ce}_{3+}$ ratio can occur (c.f. Smythe and Brenan, 2015). We investigated the effect of cerium incorporation into the structure of hydrous rhyolitic melt. hydrous ryholitic glasses quenched from melt at $1 \mathrm{GPa}$ and $1300{ }^{\circ} \mathrm{C}$ show a significant decrease of $\mathrm{H}_{2} \mathrm{O}$ solubility due to the incorporation of Ce. Pair distribution function measurement shows no distinct change in the local structures of the hydrous rhyolitic glasses with the incorporation of $\mathrm{Ce}$, while we found a distict change in the position of the $\mathrm{T}-\mathrm{OH}$ (where $\mathrm{T}$ is $\mathrm{Si}$ or $\mathrm{Al}$ ) Raman peak. The incorporation of Ce decreases the proportion of T-OH Species and increases that of $\mathrm{Q}_{4}$ and $\mathrm{Q}_{3}$ species. These results imply the occurrence of a direct charge transfer reaction between hydrogen $(\mathrm{H})$ in melt and incorporated $\mathrm{Ce}$ as: $2 \mathrm{CeO}_{2}+2 \mathrm{H}$ (melt) $\rightarrow \mathrm{Ce}_{2} \mathrm{O}_{3}$ (melt) $+\mathrm{H}_{2} \mathrm{O}$. This reaction causes a charge tranfer from $\mathrm{Ce}_{4}+$ to $\mathrm{Ce}_{3}+$ in hydrous rhyolitic melt, and it inevitably produces $\mathrm{Ce}_{3+}$. The depression of $\mathrm{Ce}_{4+} / \mathrm{Ce}_{3+}$ ratio reported in hydrous silicate melts may by due to the charge transfer reaction between $\mathrm{Ce}$ and $\mathrm{H}$, which inplies that the $\mathrm{Ce}_{4} / \mathrm{Ce}_{3}+$ ratio in hydrous silicate melts may not simply refrevt the oxidation state of magmas.

Reference:

Smythe, D. J., \& Brenan, J. M. (2015). Cerium oxidation state in silicate melts: Combined fO2, temperature and compositional effects. Geochimica et Cosmochimica Acta, 170, 173-187. 